\title{
French clone provides support for Dolly
}

[PARIS] Controversy about the authenticity of Dolly, the lamb cloned from an adult udder cell, took a new turn last week with the release by a French group of preliminary data appearing to confirm that differentiated somatic mammalian cells can be reprogrammed to make them totipotent.

In experiments carried out by Jean-Paul Renard's team at the national agricultural research agency (INRA)'s centre at Jouy-enJosas near Paris, 35 cows were implanted with 61 blastocysts created by somatic cell transfer into enucleated oocytes.

One calf, Marguerite, cloned from a muscle cell of a 60-day-old fetus, has already been born. Four other pregnancies have advanced beyond mid-term, including one obtained from a fetal skin cell containing a transgenic marker, and one from a skin cell from a twoweek-old calf.

Renard says the group took the unusual step of releasing results before publication to contribute "supplementary arguments" to the debate triggered by a letter in Science by Norton Zinder, a bacterial geneticist at Rockefeller University in New York, and Vittorio Sgaramella, a scientist at the University of Calabria in Italy (see Nature 391, 825; 1998).

The letter described Dolly as an "anecdote not a result", given that it was the only successful birth out of several hundred attempts. In particular, the authors criticized what they claimed was the poor characterization of the donor cells used, and the possibility that Dolly could have originated from a stem cell or perhaps even from a circulating fetal cell, as the donor ewe was pregnant when the cells were obtained.

The French experiments, designed to prove that cloning from adult cells is possible, answer many of these criticisms, says Renard. The possibility that the adult clone might be derived from a fetal cell is excluded, for example, because the cells used came from a twoweek-old calf that was not pregnant.

Similarly, the donor cells were carefully characterized using marker antibodies against vimentin, which is expressed in fibroblasts, against cytokeratin $3 / 18$, which is expressed only in epithelial cells, and against type $\mathrm{A} / \mathrm{Clamins}$, which are expressed only in the nuclei of differentiated cells, not in embryonic cells.

"We can exclude the possibility of any contamination from fetal cells; and the nuclei definitely come from somatic cells, not germinal or fetal ones," says Renard. He adds that the definitive evidence they have cloned from an adult cell must await the birth of the calf, and a genetic fingerprinting comparison with the source animals.

The fact that clones have been obtained from a variety of cell types also suggests that the reprogramming of differentiated soma-
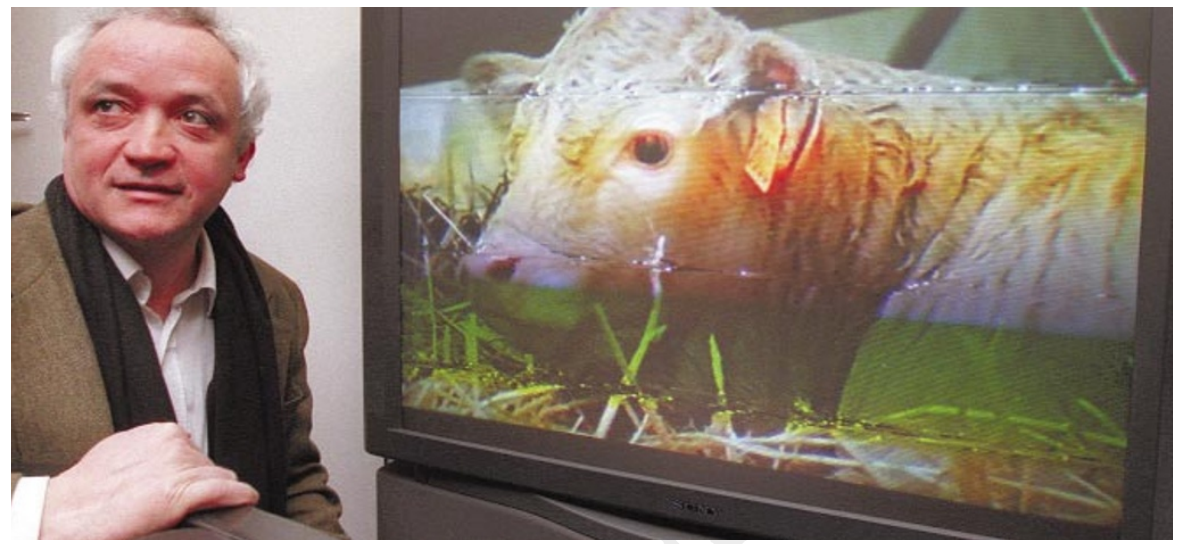

Renard with Marguerite: claims his research answers many of the criticisms of the Dolly scientists.

tic cells to become totipotent is a widespread phenomenon, says Renard. This is consistent with the claims of supporters of Dolly's authenticity, who argue that Dolly is part of a progression from the production of clones from embryos and differentiated fetal cells to the routine generation of embryos from adult somatic cells.

Commenting on the French results, Zinder said last week that the researchers should not count their chickens until they hatch, as

the pregnancies, although advanced, may yet fail. But he also says he has never questioned the possibility that cloning from adult cells may be a reality, and that his concerns focused only on the adequacy of the evidence presented in the Dolly paper.

Renard says he felt uncomfortable about releasing the data before having a paper accepted by a peer-reviewed journal. But he says he eventually felt it necessary to contribute to the controversy.

DeclanButler

\section{Congressman launches plagiarism inquiry}

[WASHINGTON] An investigation by George Brown (Democrat, California), the senior minority member on the House of Representatives Science Committee, into an allegation of scientific plagiarism at Cornell University, New York State, may be widened to look more broadly at cases in which the ideas of junior scientists are allegedly stolen by senior colleagues.

Brown's staff are investigating a case at Cornell in which Antonia Demas, a graduate student, alleges that David Levitsky, a professor of nutrition at the university, failed to give her due credit for research into techniques for improving children's diets. Levitsky vigorously denies the charge.

The staff are also gathering information about other cases, including one at the University of Michigan which last year resulted in the award of \$1.1 million in damages by a jury to Carolyn Phinney, a statistician who had worked in a psychology laboratory, after she claimed that ideas were stolen by her supervising professor.

"It is premature to come to conclusions regarding the Demas case," Brown says. "But the allegations highlight the general problem of young scholars having their best ideas stolen by senior researchers."

Cornell says it has already investigated the case thoroughly. "This set of issues has been repeatedly reviewed by many different entities," says Henrik Dullea, vice-president for university relations. "The charges were found to be unsupported," he adds, describing it as "ludicrous" to suggest that a university such as Cornell cannot investigate such allegations independently.

"If it is being suggested that I plagiarized or attempted to steal anything, that is totally untrue," says Levitsky. The inspector general at the US Department of Agriculture, which supported the research in question, also investigated the case and took no action.

But Brown believes the affair raises general issues that deserve attention. According to a member of his staff, Brown has no desire to follow in the footsteps of John Dingell (Democrat, Michigan), who fought a wide-ranging battle against what he saw as various forms of scientific misconduct for years. Instead, he will focus on junior researchers - especially women — who may be exploited by senior colleagues.

"There are many reports of such behaviour, but we cannot know how many incidents go unreported due to intimidation or fear," said Brown in a statement. "We cannot allow young scholars to be victimized. Raising questions about cases of alleged misconduct can be good for the integrity of the overall system by providing hope to victims, and giving pause to those who would be predators."

Colin Macilwain 